\title{
NOTAS SOBRE LO RELIGIOSO Y LO PROFANO EN LAS FESTIVIDADES POPULARES DE HOY
}

\section{Alberto Dallal}

\section{La fiesta latinoamericana: prolongación del rito*}

Toda acción ritual es una búsqueda de armonía. En los rituales el universo se hace sustancia y acto, actividad, objetividad, energía; aflora el deseo colectivo, el anhelo primigenio que posee el grupo de "aminorar", si no de erradicar, las diferencias que la cotidianeidad crea entre la vida de los dioses y la vida de los hombres. No hay rito o ritual sin este anhelo, de la misma manera que hasta la presente etapa de la historia, para muchos grupos humanos resulta imposible la existencia de un hombre o un pueblo que prescinda de su contraparte "divina".

No hay en la actualidad ninguna sociedad completamente atea, circunstancia que hace aumentar la importancia del ritual como acción colectiva. La des-sacralización del universo es un proceso lento e inexorable. Para algunas sociedades y culturas se trata de una acción dolorosa que hace y hará intervenir a fuerzas sociales variadas e intensas. Para cualquier creyente, la acción ritual es el camino hacia la "imagen-otra" que vive en el esplendor o en las sombras del más allá: una especie de antimateria o anti-yo que se hace necesario localizar y honrar para garantizar la supervivencia en la tierra. Prescindir de estas nociones ancestrales, tal como lo han hecho la ciencia y la organización social contemporáneas, plantea una especie de desquiciamiento filosófico y sociológico (superables sólo política y dialécticamente), pues en la cultura han quedado rotos los conductos por medio de los cuales se alcanzaba el equilibrio ante la vida terrena y la vida "otra", la vida del "más allá". Ante las posibles situaciones que propone la teoría, surgen espontáneamente obstáculos y contrastes inesperados: los grupos humanos, las comunidades comulgan y sostienen sus tradiciones, persisten en sus ritos. A veces - ha ocurrido de manera notoria en la historia de muchos pueblos- las legislaciones, aceptadas socialmente, quedan teoría, letra durante un tiempo muy prolongado antes de que la colectividad pueda prescindir objetivamente de sus mitos y ritos como actividades concretas, prácticas, funcionales.

Pero no se crea que esta búsqueda del equilibrio y de la armonía por

* Agradezco los ponderados y atinados comentarios de Martha Fernández tras la lectura del presente texto. 
medio del ritual respetó en nuestra América la forma de extrema abs. tracción que la tradición judeo-cristiana impuso en Occidente. La enorme mezcla de elementos simbólicos y de sustitutos materiales de las deidades conforma una interesante pléyade de sabias y destacadas acciones productoras y renovadoras de recursos en todo el continente. El pan de muerto, los hongos alucinantes, las hierbas medicinales y sagradas, el intercambio de amuletos y enseres prodigiosos, la ingestión de alimentos maravillosos, la profilaxis del humo y del tabaco, los frutos suscitadores y conseguidores, la elaboración e intercambio de túnicas y ropajes, la invocación de las lluvias por medio de música y bailes; en fin, la vastí. sima gama de actividades y confecciones ideadas para conseguir periódicamente el orden o la vuelta al orden en la creación, la nivelación entre las partes material y espiritual, indican que en la América hispánica ciertos procedimientos rituales anteriores a la conquista fueron sustituidos mientras otros se sincretizaron. Todos, sin embargo, adquirieron visos de acciones productoras y reproductoras de bienes y servicios. Eran hechos y obras que cumplían voluntaria o involuntariamente con el ciclo económico de cada región. Tanto la enumeración y descripción de elementos como la explicación de rituales han quedado registradas y comentadas en las crónicas antiguas, modernas y contemporáneas, y aún esplendecen las imaginerías indígena y negra, campesina y metropolitana, siempre populares en páginas y más páginas de sabrosos relatos y descripciones. ${ }^{1}$ Asimismo, las características del ritual, así como sus fuentes y orígenes han sido re-creados una y otra vez en la literatura del continente a lo largo de varios siglos. El juego del huevo y la gallina: conformar mitos y ritos que salvaguarden el proceso económico-social y viceversa: propiciar movimientos que erradiquen mitos y ritos de la antigüedad o por lo menos que los hagan más "operativos" según el desarrollo económico. social.

En un sentido más amplio podría asegurarse que el hombre (el antiguo, el contemporáneo) parece buscar una compensación entre el mundo de la naturaleza y el mundo de la cultura. No es otro el objetivo de los rituales de hoy, llamémosle deportes, manifestaciones, celebraciones o fiestas. A diferencia del espectáculo, experiencia en la que imperan totalmente los tinglados del artificio, la festividad del grupo intenta, antes que nada, abrir una o muchas puertas espontáneas entre un universo

1 Martínez Peñaloza, Porfirio indica que un Calendario de fiestas tradicionales en México registraba 12700 fiestas en el país actual, de las cuales se describian sólo 2500 por poseerse datos fidedignos, pp. 155-162. 
subjetivo y uno objetivo, crear accesos para que la energía espiritual invada la atmósfera de los objetos y los llene de indispensables significaciones. Los antiguos fetiches (productos de una creencia trascendental, mítica, o de una necesidad objetiva e inmediata, paulatinamente encubierta) se hallan más cerca de nuestro refrigerador y de nuestro librero, más cerca de las macetas y plantas de nuestras habitaciones de lo que creemos y reconocemos. Con sorpresa, pero también divertidamente, descubrimos que las hemos transformado en "supersticiones", en apoyos "fantasiosos" de nuestras alegrías y preocupaciones. No es casual (ni ocioso) que ante los embates de la contaminación atmosférica vuelva a hablarse de la necsidad de "platicarle" a las plantas, de acariciarlas y "tratarlas bien" para que se desarrollen adecuadamente dentro de los apartamentos y casas. Las macetas y los floreros no sólo recrean nuestro sentido de la vista; también hacen penetrar a la naturaleza en un acto de reconocimiento y de silenciosa, oculta adoración. La extensión de esta pleitesía se expresa con claridad en las flores blancas de las bodas, en los zempa. zúchiles del 2 de noviembre (día de muertos en México), en las rosas rojas de los cumpleaños, en las azucenas del viernes santo; ida y vuelta de Ias divinidades, sucesivas penetraciones en dos tipos de espacio completamente diferentes, irrupción de tiempos que el hombre contemporáneo cree totalmente idos. Pero también se manifiesta en los carteles y pinturas que reproducen los rostros de los dirigentes de la liberación latinoamericana, en las tarjetas postales, en las fotos "pintadas", los llaveros, los adornos, los "colguijes". Es más: no sólo acaece a través de estos intersticios la compenetrabilidad objetiva-subjetiva sino también la fusión histórica: ${ }^{2}$ en nuestros utensilios, juguetes y enseres de plástico estos elementos se repiten hasta la saciedad, sólo que, si las circunstancias lo propician, con los inestimables elementos de una sociedad que se apropia de los objetos "traidos de otras tierras" para asimilarlos y hacerlos suyos de una manera distinta, mediante una actitud distinta: el objeto es funcional y por tanto me corresponde utilizarlo; pero habré de adap-

2 "Esta complejidad de pensamiento lleva al hombre colonial a la aceptación de una casualidad dual que jamás siente como contradictoria: el amuleto o remedio preventivo contiene a la vez un elemento empírico y un elemento mágico er armoniosa conjunción. $\mathbb{E l}$ uso en amuleto de las propiedades físicas del ajo, la cebolla, el chile o el tabaco es en la práctica ilusorio, dada la forma de su empleo, mas de cualquier modo pone de manifiesto una cualidad causal que es útil al hombre mezclado para conciliar los conceptos operantes en el mundo naturalista del indigena y el mundo racionalista del español. Esa misma dualidad le permite separar ambos conceptos cuando se ve acusado de supersticioso ante el Santo Oficio de la Inquisición." Aguirre Beltrán, pp. 203-204. 
tarlo a mi albedrío y necesidades: le pondré un nombre nuevo, lo usaré a mi modo y según mi tradición.

Tampoco son casuales las evidentes tendencias de las clases medias urbanas a "regresar", aun simbólicamente, a las prácticas "artesanales": se elaboran artefactos, se construyen muebles, se "hace talacha" mecánica y electrónica con el deseo oculto y controlado de utilizar las manos tan diestramente como los antepasados, toda vez que en la electrónica y la cibernética cotidianas no visualizamos el estrecho contacto que gremios, cofradías y agrupaciones artesanales guardaban con las sencillas deidades, los patronos, las representaciones simbólicas.

Otros tipos de rituales contemporáneos, como los matrimonios y las fiestas de quince años, nos permiten atisbar un heredado prurito de participación que en salones de baile, en salas pequeño-burguesas y en otros amplios recintos se hacen evidentes. Por ejemplo, la boda actual comparte con las de hace muchos siglos la costumbre de atestiguar el desenlace sexual, aunque en la actualidad púdicamente quede la imagen sólo en la mente de los invitados a la reunión. Asimismo, en la celebración acogemos inconscientemente la pérdida de sensaciones y experiencias espirituales olvidadas, sólo relativamente superadas, pues la simbología resulta demasiado elocuente en el grado de riqueza que despliegan los anfitriones. ${ }^{3}$

La incorporación de estas entidades duales (civiles-religiosas, funcionales-míticas) a las costumbres de hoy se lleva a cabo más lenta, elocuente $\mathrm{e}$ inexorablemente de lo que alcanzamos a percibir en nuestra vida cotidiana. Pero también más dolorosamente. La llegada del tiempo de las cosechas hace que se reúnan en los pequeños pueblos de América Latina personas que cada vez con más obviedad tienen menos bienes materiales que compartir, menos servicios que otorgar, menos alegrias espontáneas y hasta menos símbolos suyos, nativos, autóctonos que celebrar ante el embate de los símbolos y signos de una jerarquía social que se halla por encima de ellos y los asfixia, incluso en sus mundos más subjetivos. El recién ingresado en el proletariado industrial de las ciudades grandes y medias de América Latina, pocas oportunidades tiene ahora (a diferencia de la década de los veinte y Ios treinta) de incorporar a su modus vivendi los pequeños elementos que salvaguardaban su tradición,

3 "La monogamia fue un gran proceso histórico, pero al mismo tiempo inaugura, juntamente con la esclavitud y con las riquezas privadas, aquella época que dura hasta nuestros días y en la cual cada progreso es al mismo tiempo un xegreso relativo y el bienestar y el desarrollo de unos verifícanse a expensas del dolor y de la represión de otros." Federico Engels, p. 73. 
su estabilidad cultural, sus bienes sociales; tampoco puede hacerse de otros que, si bien nuevos, podía compartir con los miembros de la capa social que se hallaban en iguales circunstancias. La Coca Cola, el televisor, las historietas cómicas, las hamburguesas, el catsup, la música de rock, las camisetas grabadas y un sinnúmero de aparatos, objetos y actividades impuestos por el colonialismo contemporáneo a través de muchos conductos no son sólo irremediables improvisaciones dentro de una vida con hondas raices culturales, sino elementos de erradicación de todo tipo de reductos, por medio de los cuales aflore hacia la superficie de la vida y la cultura latinoamericana actuales un buen número de mitos, hechos, cualidades, relaciones y segmentos provenientes de la caracterología social primigenia. El fenómeno podría compararse con la hecatombe del árbol cuyas raíces han quedado muertas sin que nadie lo sepa, al mirar y admirar el tronco y las ramas. Por ello es tan importante la proposición sistematizada de formas artísticas que recuperen o por lo menos re-creen la atmósfera cultural vernácula por medio de técnicas (procedimientos) de hoy. Espíritus, espacios, actitudes, procesos, leyendas, nombres, terminologías ancestrales propuestas mediante elementos inmediatos, cercanos, actuales. De no lograrse esta simbiosis, esta armonía, los pueblos conquistados o sojuzgados, así como las clases sociales que los sustentan, requerirán de modos violentos para permitir que sus expresiones hagan acto de presencia, logren la diferenciación o la distinción a las que se saben acreedores, toda vez que los hábitos, las costumbres son tácitas identificaciones; son cabalmente cultura. Está probado que tarde o temprano las nacionalidades requieren de esta manifestación libertaria de sus símbolos fundamentales y a lo largo de la historia el conquistador más hábil ha sido aquel que permite, aun suave o encubiertamente, la supervivencia de dichos símbolos. ${ }^{4}$ Esta trágica operatividad del sojuzgamiento no sólo es tendencia de las naciones coloniales, sino también de las clases hegemónicas en el interior de los fenómenos nacionales:

Cuidado con el vacio que sobreviene cuando en una ciudad se desplaza un monumento, se destruye un árbol, se hiela un parque, se parte en dos una guarida urbana: hay un espacio que se extingue, un sentido que se corrompe, un esfuerzo históxico que se desecha, un relato que

á "Los incas fueron hábiles políticos y nunca trataton de destruir de golpe los valores culturales de los pueblos conquistados. Si bien imponían el idioma quichua y el culto del sol en el templo correspondiente, en cambio no negaron a los grupos incorporados la continuación de sus cultos y el uso de su idioma." Hardoy, p. 408. 
deja de ser repetido... porque no vienen elementos opuestos o similares a sustituirlos, a actualizarlos, a sintetizarlos. Deja de haber función y aparecen los prejuicios. ${ }^{5}$

Por todo esto resulta difícil y peligroso negar tajantemente la incorporación al arte urbano, cosmopolita o de vanguardia, de elementos nacionales que subyacen en el humus creativo pero que, o bien son considerados carentes de valores universales, o bien son calificados de expresiones nacionalistas estrechas. Los parámetros de este interjuego de valores nacionales e internacionales deben analizarse, para llegar a conclusiones, bajo las bases más estrictas de información objetiva en torno a las circunstancias sociales y políticas en las que este interjuego tiene lugar. En el plano de la cultura sobrevienen enfrentamientos violentos, de los cuales casi nunca nos percatamos, ya que los elementos y símbolos nacionales y locales son, la gran mayoría de Ias veces, si no todas, modelos microcósmicos de mundos mayores cuyo origen resulta localizable a cientos de años de distancia. ${ }^{6}$ En la destrucción de los pequeños detalles nacionales pueden existir cosmos enteros, símbolos gigantescos. Si este fenómeno de miniaturización simbólica es tan obvio y claro de significado en los juguetes contemporáneos y en el folklore de todos los siglos, ¿por qué no apreciarlo, reconocerlo y respetarlo en instancias indigenas, aborígenes y nativas? Por lo menos, el estudioso y los grupos sociales militantes y participantes de la economía, la política y la cultura tendrían la obligación de: 1) recoger las características de las manifestaciones y descubrir las condiciones en las que éstas sobrevienen, y 2) interpretar y seleccionar los materiales aún practicables y adjudicables a las formas contemporáneas de la cultura. ${ }^{7}$

\section{Fiesta y tradición}

Las raíces religiosas de las fiestas latinoamericanas se hacen patentes sobre todo en paises en los que se desarrollaron culturas indígenas antes

5Dallal, Alberto, "Iradiaciones", Revista Mexicana de Cultura, suplemento de El Nacional, vI época, núm. 87, 9 de septiembre de 1979, p. 10.

6 "El escalamiento puede funcionar igualmente en sentido contrario, utilizando un modelo en gran escala para una realidad percibida como menor "Las enormes montañas que habitan los dioses ancestrales son versiones mayores de las casas zinacantecas Los pozos de agua más grandes, 'baños' de los dioses, son símbolos ampliados de los pozos utilizados diariamente por los zinacantecos." Vogt, p. 27.

7 "... es verdad que existe una 'moral del pueblo', entendida como conjunto determinado (en el tiempo y en el espacio) de máximas de conducta práctica y de cos. tumbres que se derivan de ellas o las han precedido, moral intimamente relacionada, 
de la llegada de los españoles, portugueses e ingleses. Países como México, Perú, Bolivia, Ecuador, Brasil y otros, se singularizan por la enorme cantidad de celebraciones de origen religioso, que hasta la fecha se realizan en ámbitos intocados o bien en tinglados que han sufrido pocos cambios desde épocas inmemoriales. En el calendario mexicano se entremezclan las festividades religiosas y civiles, alcanzando más de 120 días de fiestas entre celebraciones de batalla, santos, instauración de instituciones, etcétera. Las poblaciones del campo gustan de establecer sus fiestas con base en elementos decorativos y ornamentales que adornan atrios, calles, plazas, casas y hasta parajes campiranos "Asimismo, alimentos especiales, preparados de antemano, dan lucimiento a la celebración. La música es elemento fundamental en las festividades, ya que da apoyo tanto a danzas como a cantos y obras teatrales. Buen cuidado tienen los indígenas y pobladores del área rural de confeccionar trajes y vestiduras que armonicen con los fervores de su celebración. Asimismo, tienen una enorme tradición la instalación de juegos de artificio (cohetes, luces, toritos, etcétera), ya que subraya la imaginería de las festividades.

Como ocurría ancestralmente, sólo un grupo de iniciados posee los conocimientos suficientes y adecuados para preparar la fiesta y realizar los requerimientos objetivos de la festividad. Si en la época prehispánica eran los sacerdotes y los guerreros los que tenían la experiencia y los conocimientos suficientes, en la Colonia los clérigos hicieron descansar sobre las espaldas de los más duchos y convencidos la empresa de la celebración. En la época actual se han creado comités especiales que incluyen a los más aptos, los más interesados y los más convencidos para efectuar trámites y para preparar tinglados. La estructura civil permite sustiiuciones. Naturalmente, los cantores y danzantes son personas que a lo largo de sus existencias han tenido buen cuidado de estudiar y ensayar los cánticos y las danzas que expresan con honor el sentimiento de las celebraciones. Tanto las autoridades civiles como religiosas tienen buen cuidado en estatizar el sentido de la fiesta con el objeto de salvaguardar no sólo el honor, sino también el poder. Si bien se establecen

como la superstición con las creencias religiosas reales: existen imperativos que son mucho más fuertes, tenaces y eficaces de los de la 'moral' oficial. También en esta esfera hay que distinguir distintos estratos: los fosilizados, que reflejan condiciones de vida pasada $y$, por tanto, son conservadores y reaccionarios, y otros que son una serie de innovaciones, a menudo creadoras y progresivas, determinadas espontáneamente por formas y condiciones de vida en proceso de desarrollo, y que se encuentran en contradicción o meramente en discrepancia con la moral de los estratos dirigentes." Antonio Gramsci, pp. 489-490. 
competencias entre una población y otra, poco puede hablarse de oposición entre una categoría social y otra, ya que por tradición, en las fiestas latinoamericanas las celebraciones se hallan encaminadas a hacer perdurar el ejercicio de un núcleo hegemónico sobre el resto de la población.

A pesar de todo, tanto las beatificaciones como las consagraciones y las demás fiestas religiosas, de una o varias maneras vinculan a pobladores de regiones enteras. Los ritos que surgen de estas celebraciones pueden llegar a sorprendernos, no sólo por su esplendor e imaginería, sino también por la destreza con la que se manipulan los elementos y las experiencias de la festividad para que los núcleos de población, tervorosos creyentes del mito civil o religioso, queden convencidos de que el fenómeno ritual se halla plenamente justificado. De la misma manera que la Iglesia tuvo buen cuidado de establecer el culto a una "Virgen Morena", mestiza, netamente mexicana, se buscó que las festividades expresaran una lógica local que de alguna manera "premiara" los desvelos y trabajos de la población del lugar. De ahí que los festejos para celebrar canonizaciones, dedicaciones, nacimientos, bautizos, muertes, surgimientos, apariciones, etcétera, tuviesen un sabor nacional o local que adjudicara a los pobladores del lugar cualidades y características que en ocasiones sólo era posible pensar en habitantes de regiones distantes. Los sagrados ritos quedaban así "asuntados" a los requerimientos propios: los procedimientos y preparativos adhirieron costumbres, galardones, alimentos, colores y materias a las inclinaciones del momento histórico. Lo mismo ocurrió en el proceso de incorporación de aspectos netamente literarios: letanías, poemas, letras de canción, sermones, acertijos, etcétera: de pronto parecían haber surgido en el lugar en que se celebraba la fiesta, cuando en realidad eran "elementos disfrazados" que los grupos hegemónicos propiciaban, promovían, ofrecían o abiertamente imponían.

La modernización de estos juegos y celebraciones de artificio ha dado lugar a que en zonas urbanas de toda América Latina se incluyan durante las festividades civiles y religiosas numerosas lüces de colores que popularizan efigies e imágenes, y que destacan la importancia del sentido de la vista en la fiesta popular. Los fuegos artificiales llegaron a tener una manufactura artística sorprendentemente desarrollada en México y en otros países del continente durante los siglos xvI y xvII. Muchas crónicas hablan de los fuegos de artificio que se quemaron durante celebraciones como la beatificación a San Felipe de Jesús, Santa Rosa de Lima o durante fiestas como las dedicadas a San Juan Evangelista, la Virgen 
de Guadalupe, San Agustín o la Purísima. Suficientes cantidades de dinero se dedicaban a preparar y quemar soles de chispa, jarillas, cohetes, rehiletes de fuego, luces de bengala, luminosas estrellas y soles enteros. Durante los desfiles las luces de artificio lucian en plazas y paseos y se quemaban en azoteas, fachadas, atrios y torres-campanarios. La combinación de estas artes con las del diseño de la vestimenta hablan de una necesidad de armonía entre colores y luces, entre texturas y telas, entre bordados y detalles pirotécnicos. Esto de puertas afuera. Una vez llevada a cabo la ceremonia, la gente entraba en tinglados específicos, como salones y plazas de toros, de tal manera que se iniciaba puertas adentro la prolongación de las celebraciones exteriores. ${ }^{8}$

El toreo, la fiesta brava quedó asimilada fácilmente en la América española. Tanto su condición efímera como su pasión efectiva y el juego visual de sus luces llamaron la atención de los pobladores de la América colonial, de tal manera que tiempo y espacio se trasplantaron a las plazas de toros de México, Caracas y Lima sin menoscabo del esplendor poderoso que hacia reaccionar a una enorme cantidad de espectadores. Asimismo, lo taurino hace nacer en las poblaciones criolla y mestiza las costumbres que se adhieren a la fiesta brava, hábitos complementarios que dan un toque especial de algarabia a eso de "ver los toros": se instalan cafés, cervecerías, cantinas, comederos y puestos de fritangas para comentar en voz alta y hasta cantar las faenas de esos monstruos llamados toreros. Ser de los iniciados en la fiesta brava, pertenecer al núcleo de los conocedores de esta verdadera ceremonia o rito (no pertenecer a la odiosa chusma de los "villamelones") implica una categoría especial admirada por el público, por el pueblo. El ritual posee tantos secretos. como la misa y otras ceremonias religiosas. La alternativa consiste, para el poblador común y corriente de las ciudades de América Latina, en poseer la clave de los secretos que pululan durante la festividad en la plaza de toros. Se trata de una fiesta singular que libera gustos, inclinaciones, afectos, pasiones; se trata de una estética del rito, ${ }^{9}$

Pero si hay fiestas que surgen por imitación o por comunicación y comunión, hay otras que surgen por contraste. Contraste social o económico. Una de ellas es la inclusión de alimentos específicos de la región o de otros lugares de los que son traidos para engalanar festividades. locales. Encubrimiento de la necesidad de comer es el efímero placer del banquete. Asimismo: importancia en las categorías sociales. La falta

8 Martínez Marín, Carlos, "La pirotecnia", en El arte efimero en el mundo hispánico, pp. 201-223,

9 Rangel, Nicolás, Historia del toreo en México. Época colonial (1529-1821). 
de alimentos que indica la pobreza de muchas regiones de América Latina contrasta con la diversidad de platillos y guisos y con la capacidad de pasatiempo que algunas artes culinarias americanas expresan. El buen comer y la gula no pueden adaptarse a situaciones de limitada producción. La comida completa, la ceremonia, el rito, la celebración. La inventiva de la población americana en el arte de preparar alimentos, por una parte, contrasta con la pobreza de las mayorías pero, por otra, habla y expresa la instauración de satisfactores indispensables. Los platillos y guisos que engalanan las mesas de los ricos son el derroche de aquellos productos que muchas veces salen del continente sin ser tocados o conocidos por la mayor parte de la población. Pero como un anuncio ciel autodominio talentoso de esos mismos alimentos, muchas veces los americanos exportan fórmulas, maneras de hacer alimentarias que sorprenden a europeos, asiáticos y nórdicos por su enorme riqueza imaginativa.

Especial realce se ha dado a partir de la Colonia a los ámbitos y tinglados teatrales. Puede afirmarse que todo tipo de estructura social intenta, en América Latina, expresarse por medio de un esquema formal que en el espacio resulte armónico con su naturaleza. Tanto el dolor como el regocijo son en América Latina mototes para el epectáculo. Hay esquemas que armonizan con la sensibilidad americana y que se traducen en altares, carros alegóticos, grupos bailables, procesiones, estructuras de carnaval, mascaradas, etcétera. En todas partes la fiesta requiere del adorno y éste da lugar a verdaderas esculturas fabricadas con materiales diversos, a veces perdurables, a veces perecederos. Los habitantes de América Latina, para esto, echan mano de pinturas y colgaduras de varas y ramas de árbol, de pajas engalanadas con colorantes. A veces las mismas bestias que se utilizan para hacer producir a la tierra, quedan, tras el adorno, como símbolo o representación de alguna deidad o santo. En ocasiones se reproducen efigies, imágenes, rostros. En otras se ridiculiza el mal, el diablo, las acechanzas, el enemigo. Hay lugares en que se reproducen anécdotas e historias y las lucidas fiestas quedan completas con descripciones habladas y recitativos. En la época contemporánea estos aditamentos verbales se sustituyen con melodías populares, mientras que el aspecto escultórico queda reflejado en farolitos, listones, estampas, fotografias, virutas coloreadas y todo tipo de implementos incluyendo aquellas máquinas, autos y tractores que coadyuvan a los trabajos rurales y proletarios. La música y el vestuario se adaptan a las circunstancias y comienzan ya a escucharse las canciones 
de protesta, los versos agresivos y antimperialistas en fiestas locales en las que los festejantes se regodeaban con músicas y letras completamente pasivas.

Todo lo anterior indica que la tradición hispánica de la fiesta proviene de un sentido originalmente religioso y ritual, cuyo proceso de liberación se ha llevado siglos enteros de desenvolvimiento, recreación, hibridización e inventiva. La fiesta en América Latina es una estructura cultural que se reproduce espontáneamente y que va incluyendo todos los elementos sociales e históricos que indican la naturaleza misma del habitante local. Ante la enorme influencia de los medios de comunicación masiva, los grupos sociales organizados de América Latina no pueden permanecer a la expectativa de los resultados, sino aprovecharse de ellos para que se conviertan en vehículos trasmisores de los elementos y hábitos originales. Buen ejemplo de esta posibilidad radica en algunos programas de televisión en los que se atrae la creatividad musical del habitante urbano americano. Los ritmos netamente locales resultan más ricos y atractivos para los espectadores o televidentes que aquellas formas y modalidades musicales traidos "tal cual" desde los Estados Unidos y Europa. Asimismo, puede hallarse una acción liberadora en la transformación de tiendas y servicios comerciales en puntos de reunión específicos, en los cuales la población latinoamericana se dé cita para recrear sus propios ritos y costumbres. Alrededor de los grandes almacenes de tipo norteamericano deben surgir cafés, peñas, puntos de reunión, puntos de venta que salvaguarden los productos y los hábitos alimentarios de los distintos pueblos latinoamericanos. En estos mismos lugares se pueden asimismo escuchar las melodías propias de la región y adoptarse los bailables, ritmos y canciones que por siglos caracterizaron a los moradores del continente.

\section{La fiesta comprimida}

A diferencia de los actos rituales, la fiesta latinoamericana, una vez lograda la independencia política de España y Portugal, tiende a romper los símbolos, los elementos representativos básicos. A diferencia del espectáculo (por antonomasia medio transmisor de signos tradicionales), la fiesta genera vínculos con las circunstancias, propone "formas de expresión" ad hoc para las nuevas situaciones políticas e históricas. La inclusión de la fiesta "cívica" (o la transformación de la celebración patriótica en fiesta) en el calendario secular de las nuevas naciones representa un cambio en la acción de generar procedimientos festivos. 
En este punto, la tradición (costumbres y hábitos españoles en contubernio, cuando los hay, con los ritos indígenas) se une a la espontaneidad. Mientras que en el rito se repiten las peculiaridades de la relación entre sexos, las características de la vinculación del hombre con la tierra, las cualidades de las actividades laborales, en la fiesta surgen las posibilidades de erradicación de las antiguas (o anticuadas) ceremonias. Las fiestas son ritos popularizados mientras las manipulan núcleos gobernantes o dictatoriales; en cuanto "la chusma" se apodera de ellas se convierten en expresiones (a veces un tanto explosivas) de los deseos no realizados, de acciones reprimidas. Mientras el espectáculo constituye simbólicamente la adopción o el acatamiento de una ley, la fiesta significa la transgresión de las normas establecidas. Aunque vigiladas, cuidadas, observadas por los núcleos de poder, las fiestas, aun por un lapso contado con los dedos, temporalmente limitado, constituye una efusiva manifestación de vías de expresión nuevas.

La era virreinal dejó hondas raíces en América Latina. El mestizaje cultural y étnico, a partir de lo impuesto, logra crear nuevos elementos de cultura. En realidad, los productos ceremoniales y culturales de hoy conjugan modos de ser antiguos y energías actuales. Los festejos de los esclavos negros, por ejemplo, prohibidos en todas las zonas en las que la emigración negra resultaba contundente y peligrosa, asumieron características eclécticas, a veces disfrazadas. Los pivotes que las autoridades coloniales dejaron al descubierto y funcionando representaban una posibilidad de tranquila ocupación. En Venezuela, Haití, Cuba y, en general, toda la zona del Caribe y del Golfo de México, dan fe de Ia actitud de las autoridades coloniales. Les "permitían ciertos días de fiesta y aun que tomasen parte organizadamente en rumbosos desfiles. Se trataba, no de complacer a los negros, sino de facilitarse la ilusión de cierto albedrío, cultivarles el sentimiento de que podrían realizar sin trabas ciertos actividades propias..." 10 Algunos de los elementos fundamentales de estas celebraciones (instrumentos musicales, cánticos y letanías revisadas debidamente, danzas no demasiado desinhibidas, etcétera) fueron conservadas con el beneplácito de las autoridades, toda vez que, como las canciones religiosas, ahondaban en el sentimiento religioso y aparentemente no se oponían a su encumbramiento y desarrollo. La nostalgia de otras tierras, sin embargo, se halla presente, aún de manera encubierta y la satisfacción del recuerdo en ritmos, tiempos, actitudes. Para el siglo xviII las añoranzas ya no estaban tan a flor de

10 Acosta Saignes, Miguel, Vida de los esclavos negros en Venezuela. 
piel y más bien había surgido cierto sentimiento de soterrada oposición a las situaciones políticas, sociales, económicas que los grupos estaban obligados a padecer. Muy a su pesar, los eclesiásticos tenían que encubrir las noticias que llegaban de sociedades o grupos liberados. Así, la plañidera del recuerdo va cambiando de orientación, de sentido y cierta violencia encubierta aflora en celebraciones, cánticos, danzas, recitaciones.

Las limitaciones comienzan a ser aplicadas tanto a las alegrías como a las tristezas. En los documentos alusivos pueden apreciarse hoy en día las reticencias de los religiosos. Debe tomarse en cuenta que ya existían algunos negros libres que por servicio, fe o encumbramiento económico daban ejemplo non grato a las mayorías. Las festividades encomendadas a los patrones, jefes y comandos aristocráticos intentaban una separación tajante de terrenos, pero por fuerza -lo sabían a la perfección- debían compartir, aunque fuese mínimamente, las peripecias, repeticiones, regocijos, espectáculos, procesiones y no pocas viandas de las proporcionadas para conferir esplendor a las fiestas. A lo largo de tres siglos se va reglamentando la inclusión de los grupos sojuzgados y a la vez se especifican las fiestas y los tipos de celebración que les eran permitidos a los esclavos o casi-esclavos de terrenos, cofradías, ciudades, provincias, pueblos. A veces, incluso, se conminaba a los miembros de las clases trabajadoras a acudir a las celebraciones, toda vez que era mejor mantener la vigilancia estrecha dentro de una relativa actividad regocijante que tratar de adivinar si el silencio y el aislamiento no propiciaban ya algún levantamiento, como los que ocurrieron a lo largo de la historia colonial.

La singularidad de estos actos festivos, sin embargo, no se halla registrada sino reducidamente. Las peculiaridades de los cánticos y los hábitos dancísticos debieron aparecer espléndidas en toda América dentro de los límites de los núcleos de esclavos y sojuzgados. Muy poco de ello (sólo lo permitido) tenuemente prolongó su influencia durante la época colonial y por ello los sucesivos gritos de independencia política irradian también visos de una revolución cultural que hasta la fecha no ha sido realizada completamente. Las clases medias latinoamericanas, que abrevaron fundamentalmente en las fuentes del mestizaje, también han tenido de suyo cierto olvido, pesaroso de las costumbres, ritos y festividades autóctonas y algunos reductos, como los ritmos negros caribeños, han trasladado, evolucionados, sus "elementos de gozo" hacia modalidades y modas dancísticas y musicales. 


\section{Recreación de la fiesta}

La independencia de los países del continente hace aflorar la secularización de las fiestas. Si antes las líneas referenciales de las celebraciones marginales habían permanecido agazapadas en el calendario de los países hispanos de América, ahora saltan a la vista la necesidad de expresión festiva y el alborozo ante una nueva dimesión histórica. En última instancia, toda fiesta (religiosa o no) contiene un matiz político en tanto que manifiesta un "modo" de alborozo, una cultura del cuerpo y una sensibilidad de la comunicación colectiva. Hay fiestas que son verdaderas repeticiones de sucesos idos que por una razón u otra deben perpetuarse. Pero hay otras celebraciones cuyo aspecto festivo consiste en dar nueva energía a la comunidad y que guarda un objetivo violento (e incluso sangriento, como la fiesta brava) como prueba contundente de la habilidad física y política del conglomerado. Las fuerzas más o menos perfeccionadas de los núcleos políticos liberadores se hallaba presente en la fiesta latinoamericana que aflora durante la segunda década del siglo xix. Criollos, mestizos e indígenas proponen nuevos disfraces para las viejas celebraciones. Hay una zona desconocida, por lo menos no entendida ni manipulada, entre la fiesta religiosa (llena de seriedad y de rigores, emblema de las clases poderosas y del clero) y la fiesta que ahora debe estallar sin los miramientos o las cortapisas sociales que anteriormente pesaban bajo la ruda mirada del grupo hegemónico español y portugués. En cada revolución (por lo menos antes de que sobrevenga el "asentamiento" institucional), Ia Iglesia y las fiestas se "nacionalizan", se "expropian", vuelven a ser, en esencia, fundamentalmente, del pueblo. La fiesta, en estos momentos políticos, regresa al origen, a la comunidad de la cual brotó. El aspecto ritual se salvaguarda formalmente porque el rito, la lucha (conquista o liberación) y la fiesta son las tres formas de inmediata cohesión social, tres aspectos o fases de una suerte de "unión" instantánea, espontánea, natural, incontenible.

\section{Expresiones y ambientación de la fiesta}

La erección y construcción de tinglados funcionales y operativos para realizar celebraciones tiene una enorme y profunda tradición en nuestra América. Se trata de una herencia hispánica que parte desde la Edad Media europea y se incrusta en nuestra vida cotidiana como símbolo de la separación entre una categoría social y otra, entre una clase social y otra. Lo que al principio fue "darle atole con el dedo" al pueblo se prolongó después en la exaltación de múltiples vanidades: la aristo. 
cracia colonial debia comprobar sistemática y metódicamente el poder que ejercía sobre la masa. Prolongación del rey correspondiente, cada virrey, rodeado de su séquito, se autoproponía como prolífico bienhechor de sus gobernados. Arzobispos y obispos no se quedaban atrás en este afán de incrustarse simbólicamente en la mirada, en la vida y costumbres de los novohispanos. Comenzaba a desarrollarse una clase media adicta a la adulación del poderoso, buscadora de benevolencias, adoradora de imágenes y enferma de exagerar biografías. Los virreyes son personajes principales en las festividades civiles y religiosas $y$, por tanto, ordenan la creación de ámbitos y atmósferas adecuados. A veces se trataba de palcos, otras de tronos y lugares de honor; en alguna otra ocasión erigían arcos triunfales o plazas de toros. Todas éstas eran estructuras que simbolizaban el poder y que centraban la atención y las repercusiones en la vigencia de las autoridades, enmarcadas por aquellas personas e instituciones con las que los gobernantes compartían el poder. Con el tiempo los núcleos hegemónicos habrán de buscar otras salidas. Aunque perdurarán plazas de toros, ferias, celebraciones en centros cívicos y monumentos, aparecerán estadios olímpicos, estrados, balcones, campanarios, refuerzos todos ellos de la centralización del poder. Aunque disfra. zados, estos tinglados llaman a la creación de la fiesta, convocan a la celebración. Las plazas de ciudades y pueblos se engalanan. Suena la música. Hay comparsas. Se hacen inscripciones con flores y fuegos. Suenan los cohetes y las bandas musicales. Se trata de adornar el status, de engalanar circunstancias sociales azarosas. Con el boato no habrá impertinencias populares, aunque en algunos países, como en México, la sorna y la ironía popular brotarán inesperadamente, más tarde, en carpas y teatros de revista.

Habrá que reconocer, sin embargo, que las victorias militares independentistas también suscitaron celebraciones y alegrías. La simbología de estos fenómenos no tiene límites. Por ejemplo, durante la Guerra de Intervención (francesa) en México comenzó a acostumbrarse que las señoritas usaran zapatos de aquel color que simbolizara al enemigo en un intento asaz extraño de indicar que en algo se pisaba al contrincante. Este tipo de celebraciones alcanza incluso al arte culinario de la época. En la ciudad de Puebla de los Ángeles aparece por aquella época un platillo denominado "chiles en nogada" que con un sentido nacionalista, reúne, convoca en un recipiente los tres colores de la bandera representados por el chile, la crema y los granos de granada. Aun en la actualidad, fiestas de pueblo y fiestas urbanas se engalanan con banderines, serpen- 
tinas, heno colgado, papel cortado, efigies, letreros, pitos y sonajas. En los puestos abundan comidas como platillos, bebidas y postres que la mayoría de las ocasiones representan algo, como si la simbología local támbién alcanzara a la digestión y al estómago de los participantes.

El desarrollo del arte culinario de cada país va uncido al carro de las celebraciones y de las festividades. Este fenómeno ha alcanzado a las masas urbanas, y sus antecedentes milenarios se hallan, en algunos casos, en los tianguis prehispánicos y en los desplazamientos migratorios que sufriera la población latinoamericana durante la Colonia. Como la música, la comida es concreta, particular, propia de grupos y en algo manifiesta los pesares y los sufrimientos. Recuérdese que el esclavo posee sus propias tonadas, sus propios ritmos e instrumentos, así como los alimentos que logran caracterizarlo histórica y geográficamente. Volvemos a la singularidad del rito: la ingestión de plantas, yerbas, frutos, infusiones, parte de animal, frutas enteras, cocidas y crudas, carnes, flores y hasta insectos adquiere la importancia de una simbología trascendente, con disposición al rapto mágico, al viaje alucinado. Hay alimentos que convocan a los espiritus de la misma manera que existen brebajes que liberan y curan. Aún en la actualidad pueden verse, en los mercados, merolicos que hacen de sus explicaciones una conferencia ligera frente a las yerbas que obligan al cuerpo a sudar, que calman el dolor de muelas, que aceleran o frenan los latidos del corazón, que consuelan a paralíticos y diabéticos, que incluso hacen surgir la inspiración de los artistas (que los hay múltiples) latinoamericanos. El pueblo requiere de la chunga, del relajo, en mucho para transmitir las claves de su sufrimiento, pero también para transmitir las señales de su odio político. Todos son signos de su necesaria liberación, pues la creatividad carece de fronteras y de compartimentos estancos.

La lírica popular contemporánea en América Latina, resulta elocuente en todas estas cuestiones de la azarosa vida social y cultural de nuestros países. Música, pueblo y poesía se unen en la popular expresión de la canción latinoamericana. Piezas selectas, coros, claves, teatro bufo, varicdades, guajiras, danzones y habaneras no se proponen otra cosa que iniciar la retórica y el melodrama de lo popular. Tanto el proletariado como las bajas clases medias de todos nuestros países gustan de perfeccionar estos medios de expresión. Se inclinan por "profesionalizar" aquello que durante siglos ha sido manifestación espontánea y natural dentro de los tinglados propios de la festividad y de la celebración. Los compositores y poetas se desplazaron de lo religioso a lo cotidiano y 
vulgar; de lo intocado y sagrado a lo bajamente pasional. No hubo fuerza que los contuviera. De la misma manera, la canción latinoamericana actual ha transcurrido en dirección de lo político sin que medien transiciones notables, excepto aquellas dictadas por los acontecimientos revolucionarios. Aunque no tan arraigada como podría desearse, la canción latinoamericana de hoy intenta recabar en su seno una realidad estrujante, una suma de padecimientos sociales que necesitan ser "concientizados" principalmente en las zonas proletarias urbanas de las ciudades del continente.

Podría pensarse que las luchas sociales guardan pocas relaciones con la organización de las fiestas. Podría creerse que puede haber poca vinculación, reducidos nexos entre la algarabía de la celebración y el momento álgido de la lucha. Sin embargo (y esto se ha agudizado notablemente en América Latina), la verdadera identidad cultural y artística se manifiesta mucho más claramente en la oposición, en el combate en contra de la opresión común. Así como "los diferentes individuos sólo forman una clase en cuanto se ven obligados a sostener una lucha común contra otra clase, pues por lo demás, ellos mismos se enfrentan unos contra otros hostilmente en el plano de la competencia" (Marx), de la misma manera el surgimiento de algunas expresiones artísticas populares se ve alimentado insistentemente por la acechanza de peligros incruentos. La historia de América Latina, vista a la luz de la terrible defensa que los americanos hánse visto obligados a hacer de sus riquezas e incluso de su propia identidad histórica y geográfica, muestra una situación similar, comparable tan sólo a continentes como el africano y asiático. Podría afirmarse que el desarrollo cultural popular de América Latina constituye la suma de luchas y esfuerzos para hacer que sobrevivan valores de indentificación artísticos y culturales. Esto ha forjado una "manera de ser" múltiple, flexible. Hay obras que transgreden lo aceptable del momento. Tal el tinglado todo de la iglesia de Santa María Tonantzintla. O bien la aparente "supeditación" religiosa de los ritos prehispánicos: sus danzas y cánticos. Asimismo, la prolongación de las leyendas indigenas con nombres cristianos. $\mathrm{Y}$ así sucesivamente: la adopción de un movimiento como el balletístico (en Cuba), la proliferación de ritmos y bailables, etcétera. Todos estos elementos habrán de recrearse a su debido tiempo, en cuanto la situación social y revolucionaria permita una nueva ubicación de programas y elementos culturales nuevos. La realidad cultural de los pueblos, como la económica-estructural, jamás puede detenerse, obstruirse, destruirse por completo. 


\section{OBRAS CITADAS}

Acosta SAIgnes, Miguel. Vida de los esclavos negros en Venezuela. La Habana, Casa de las Américas, Colección Nuestros Países, 1978, 265 pp.

Aguirre Beltrán, Gonzalo. Medicina y magia. El proceso de aculturación en la estructura colonial. México, Instituto Nacional Indigenista, Secretaría de Educación Pública, lạ reimp. 1973, 443 pp.

ENGeLs, Federico. El origen de la familia, la propiedad privada y el estado. México, Ediciones de Cultura Popular, 10a reimp. 1978, 233 pp.

Gramscr, Antonio. Antología. Selección, traducción y notas de Manuel Sacris. tán. México, Siglo Veintiuno Editores, 1970, $522 \mathrm{pp}$.

Hardoy, Jorge Enrique. Ciudades precolombinas. Buenos Aires, Ediciones Infinito, 1964, $576 \mathrm{pp}$.

Martínez Peñaloza, Porfirio. "En torno a la fiesta en México", Revista de Ciencias Politicas y Sociales. UNAM, núm. 95-96, enero-junio 1979.

Ranger, Nicolás. Historia del toreo en México Época colonial (1529-1821). Editorial Cosmos, 1980, 380 pp.

Et al. El arte efimero en el mundo hispánico. México, Instituto de Investigaciones Estéticas, UNAM, 1983, $390 \mathrm{pp}$.

VoGT, Evon Z. "Ofrendas para los dioses". Análisis simbólicos de rituales zinacantecos. México, Fondo de Cultura Popular, 1979, $328 \mathrm{pp}$. 